\title{
DÜBLIN
}

Technological University Dublin

ARROW@TU Dublin

\section{Whey Permeate as a Bio-Preservative for Shelf LIfe Maintenance of Fresh-Cut Vegetables}

\author{
Ana Belen Martin-Diana \\ Technological University Dublin, anabelen.martindiana@tudublin.ie \\ Daniel Rico \\ Technological University Dublin, daniel.rico@tudublin.ie \\ Jesus Maria Frias \\ Technological University Dublin, Jesus.Frias@tudublin.ie
}

See next page for additional authors

Follow this and additional works at: https://arrow.tudublin.ie/schfsehart

Part of the Food Microbiology Commons

\section{Recommended Citation}

Martin-Diana, A., Rico, D., Frias, J., Mulcahy, J., Henehan, G., Barry-Ryan, C. (2006). Whey permeate as a bio-preservative for shelf life maintenance of fresh-cut vegetables. Innovative Food Science \& Emerging Technologies, 7, (1-2) , pp.112-123. doi:10.1016/j.ifset.2005.08.002

This Article is brought to you for free and open access by the School of Food Science and Environmental Health at ARROW@TU Dublin. It has been accepted for inclusion in Articles by an authorized administrator of ARROW@TU Dublin. For more information, please contact arrow.admin@tudublin.ie, aisling.coyne@tudublin.ie, gerard.connolly@tudublin.ie.

Funder: Technological Sector Research Grant (2002-2006).

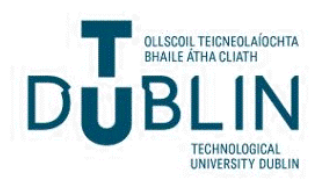




\section{Authors}

Ana Belen Martin-Diana, Daniel Rico, Jesus Maria Frias, Jemina Mulcahy, Gary Henehan, and Catherine Barry-Ryan 


\title{
Whey permeate as a bio-preservative for shelf life maintenance of fresh-cut vegetables
}

\author{
A.B. Martin-Diana, D. Rico, J. Frias, J. Mulcahy, G.T.M. Henehan, \& Catherine Barry-Ryan \\ School of Food Science and Environmental Health, Dublin Institute of Technology (DIT), Cathal Brugha Street, Dublin \\ 1, Ireland
}

Innovative Food Science and Emerging Technologies 7 (2006) 112 - 123

\begin{abstract}
Whey permeate at different concentrations $(0.5 \%, 1.5 \%$ and $3 \%)$ was used as natural sanitizing agent in the washing treatment of fresh-cut lettuce and carrots. These treatments were compared with a chlorine $120 \mathrm{ppm}$ widely used in the industry. Microbiological, quality (colour changes, browning-related enzymes, headspace gas composition, textural changes and sensory analysis) and nutritional (ascorbic acid and carotenoids) markers were monitored over 10 days in fresh-cut lettuce and carrot packages stored at $4-\mathrm{C}$. Whey permeate at $3 \%$ resulted in equivalent or better microbial load reduction than chlorine. Although lower concentration of whey permeate produced minor initial reduction, microbial counts at the end of the storage were below the recommended levels $(108 \mathrm{CFU} / \mathrm{g})$ for safety of fresh-cut vegetables. Sensory analysis panel considered all the samples of fresh-cut lettuce acceptable. However, in the sensory results the sliced carrots treated with $3 \%$ whey permeate and chlorine scored lower acceptability due to higher surface whiteness, although these samples had lower microbial loads. Three percent WP controlled the browning-related enzymes better than $0.5 \%, 1.5 \% \mathrm{WP}$ and chlorine and consequently the browning. However, this reduction in browning-related enzymes did not result in a lower browning appearance to visual observation during the 10 storage days. The use of high concentrations of WP accelerated the loss of ascorbic acid and carotenoids. These results suggest that whey permeate could be a promising alternative to chlorine for sanitizing fresh-cut vegetables.
\end{abstract}

Keywords: Whey permeate; Shelf life; Fresh-cut vegetables; Lettuce; Carrot

Industrial relevance: Many attempts have been made to increase the use of whey, a valuable by-product of cheese processing, and many attempts have been made to increase shelf life of fresh-cut fruits and vegetables. This paper takes an interesting approach by attempting to use whey permeate as antimicrobial agent. Whey permeate solution proved successful in controlling total counts via a washing step of fresh cut vegetables. Although this does not reduce the amount of whey released, it could provide use as antimicrobial prior to discarding.

\section{Introduction}

The market sales of ready-to-use fresh vegetables have grown rapidly in recent decades as a result of changes in consumer attitudes. Consumers demand a quality product that is convenient and has fresh-like characteristics (Ohlsson, 1994). Fresh-cut vegetables may be defined as those subjected to some processing techniques of lesser magnitude that canning or freezing, but which nevertheless add value to the product before the distribution and consumption. The marketing of fresh-cut vegetables is limited by their short and their decline in post-processing quality. This is due to undesirable biochemical reactions associated with wounding when compared to nontreated vegetables (Brecht, 1995; Watada, 1997).

Chlorine solutions have been widely used to sanitise fresh-cut fruits and vegetables in the industry. However, the possible formation of carcinogenic chlorinated compounds in water has called into question the use of chlorine in food processing plants (Dychdala, 1991; Page, Harris, \& Epstein, 1976; Wei et al., 1999). Moreover, the antimicrobial effectiveness of cold chlorinated water is limited due to hydrophobic plant surfaces that are believed to limit contact between chlorine solutions and microbial contaminants (Adams, 1991; Beuchat, 1992). 
There is a real need to find new alternatives for preservation of minimally processed vegetables in order to improve the efficacy of washing treatments. This will lead to increased microbial safety and extend the quality retention of the product. Alternatives or modified methods have been proposed, however, none have yet gained widespread acceptance by the industry. These include organic acids, essential oil treatments, irradiation, heat-shock, ozone treatment, etc. (Loaiza-Velarde, Tomas-Barberan, \& Salveit, 1997; Ponce, Roura, Del Valle, \& Fritz, 2002; Singh, Singh, Bhunia, \& Stroshine, 2002).

This has lead to a renewed interest in the use of natural products as decontaminants. Research and commercial applications have shown that natural antimicrobials could replace traditional sanitizing agents (Cherry, 1999; Graham, 1997). However, these new methods have not always been adopted by industry. Previous work in this laboratory showed that treatments such as heat-shock or calcium lactate washing were effective in the preservation of fresh-cut vegetables. Moreover, these methods served to enhance the nutritional value of the treated vegetables (Martin-Diana et al., 2005a,b).

Whey is a by-product of the cheese industry. Approximately, $9 \mathrm{~kg}$ of whey is produced for every kilogram of cheese manufactured. The high chemical oxygen demand (COD) (50 $\mathrm{kg} \mathrm{O}$ /ton permeate) of whey makes its disposal a significant pollution problem. In order to minimize environmental impacts different uses for this waste material have been devised by the dairy industry. The use of whey as a fermentation feedstock has long been of industrial interest for the production of lactic acid, acetic acid, propionic acid, ethanol, and single cell protein (Bogaert, 1997; Tyagi \& Kluepfel, 1998; NyKanen, Lapvete-“ lainen, Hietnen and Kallio, 1998). However, these applications still do not utilize all the whey produced and new uses for this byproduct are continually being sought. Whey permeate (WP) is obtained as a by-product when whey proteins are concentrated by ultrafiltration to produce whey protein concentrate.

The use of WP for food preservation has been examined by Nykanen, Lapvetelainen, Hietnen, and Kallio (1998). These“ authors analyzed the effect of WP washing solutions on total counts and sensory characteristics in rainbow trout. They found that WP treatment gave a reduction in total counts and had no negative effect on sensory attributes. The aim of this study was to examine the applicability of using acid WP as a biopreservative for washing of fresh-cut vegetables. Vegetables were washed in various concentrations of WP solutions and several shelf life indicators were monitored for comparison with chlorine treatment. pack was analysed individually to minimise the variability of the product. For sensory analysis samples from the whole storage bag were analysed. For destructive analysis (enzymes, ascorbic acid, carotenoids, dry matter and microbiology) samples were taken from a pool of all the pieces in a storage bag.

\subsection{Processing and experimental set up}

Iceberg lettuce (Lactuca sativa sp.) and carrots (Daucus carota sp.) were purchased in a local supermarket and stored at $4-\mathrm{C}$ before processing. For each vegetable, lettuce or carrot, four washing treatments were conducted in parallel, prepared from the same batch of product. The samples were sanitised with chlorinated water (120 ppm) and WP at different concentrations (0.5\%, 1.5\% and 3\%). For lettuce, the two outer leaves were removed by hand and the core was excised with a stainless steel knife. The other parts of the lettuce were cut in half and each half was further cut into four pieces. Carrots were rinsed briefly prior to peeling ( $1 \mathrm{~min}$ at $18-20-C)$ in order to avoid soil contamination during peeling. They were hand-peeled, in one direction using a manual peeler, removing a minimal amount of surface tissue. The carrots were then sliced manually with a sharp knife into discs approximately $5 \mathrm{~mm}$ in thickness. The temperature in the processing plant was $18-20-\mathrm{C}$.

Washing treatments of lettuce and carrots were performed by immersion of the fresh-cut vegetables in each treatment solution. Chlorinated water was prepared by adding sodium hypochlorite solution (! $120 \mathrm{~g} / \mathrm{L}$ available chlorine) to distilled water to obtain $120 \mathrm{mg} / \mathrm{L}(120 \mathrm{ppm})$ free chlorine $(\mathrm{pH}$ " 8$)$. Delactosed, acid whey permeate (WP) (UHT, supplied by Glanbia, Ireland) was diluted to $0.5 \%(\mathrm{pH}=3.84), 1.5 \%$ $(\mathrm{pH}=3.53)$ and $3 \% \mathrm{~mL} / \mathrm{L}(\mathrm{pH}=3.45)$. For all treatments the solutions were prepared using distilled water stored at room temperature (18- $20-\mathrm{C})$. Each treatment was carried out in different baskets ("200 g vegetable product/L) and immersed the solution for 1 min with agitation and subsequently dried for 5 min using an automatic salad spinner.

Free chlorine concentration in the washing water was determined using a DREl/2000 spectrometer with appropriate AccuVacı pillows (Hach Company, Loveland, Colorado, USA), using the DPD method.

Processed vegetables were pooled, mixed and subsequently packaged in bags (200 Â $320 \mathrm{~mm}$ ) of 35 Am oriented polypropylene (OPP) (Amcor Flexibles Europe-Brighouse, United Kingdom). Each package contained "100 g of product. The packages were chilled in a blast freezer at $0-\mathrm{C}$ for $2 \mathrm{~min}$ before heat-sealing under atmospheric conditions and storing at 4 oC for 10 days.

\section{Materials and methods}

\subsection{Sampling and treatment design}

The experiments were carried out between May and October 2004. Three independent trials were carried out for each vegetable. Lettuce and carrot were selected since they are the most popular fresh-cut products in Ireland and represent the behaviour of two different vegetable models (leafy and root). For colour and texture analysis each piece of vegetable in the storage

\subsection{Shelf life parameters}

The shelf life can be defined as the length of time which the vegetable can maintain the appearance, safety and nutritional value that appeals to the consumer (Delaquis, Stewart, Toivonen, \& Moyls, 1999), for that reason analysis of quality (headspace, dry matter, $\mathrm{pH}$, colour changes, texture and sensory analysis), 
microbial (mesophilic, psychrotrophic and lactic acid bacteria) and nutritional (ascorbic acid and carotenoids) markers were monitored throughout the entire storage (10 days) in fresh-cut lettuce and sliced carrots stored at 4 -C.

\subsubsection{Quality markers}

2.3.1.1. Gas composition changes. Changes in $\mathrm{CO}_{2}$ and $\mathrm{O}_{2}$ concentration of the headspaces of the fresh-cut vegetables packages were monitored during the shelf life of the product. A Gaspace analyser (Systech Instruments, UK) was used to monitor levels of $\mathrm{CO}_{2}$ and $\mathrm{O}_{2}$. Gas extractions were performed with a hypodermic needle, inserted through an adhesive septum previously fixed to the bags, at a flow rate of $150 \mathrm{~mL} / \mathrm{min}$ for 10 $\mathrm{s}$. Three bags per treatment were monitored for each experiment and the bags for other analyses were measured separately.

2.3.1.2. $\mathrm{pH}$ measurement. Ten-gram sample of vegetable tissue was blended for $2 \mathrm{~min}$ in $20 \mathrm{~mL}$ of deionised water. The $\mathrm{pH}$ of the slurry was measured at room temperature using an Orion research $\mathrm{pH}$-meter between 18 and $20-\mathrm{C}$.

2.3.1.3. Dry matter. A weighed piece of lettuce or a slice of carrot was heated at $100-\mathrm{C}$ for $2 \mathrm{~h}$ in a Universal Oven (Memmert, Schwabach, Germany). Dry matter was calculated using the weight after heating as a percentage of the initial weight.

2.3.1.4. Colour measurement. Colour was quantified using a colorimeter (HunterLab, UK). A lettuce piece or carrot slice was place directly on the colorimeter sensor ( $3.5 \mathrm{~cm}$ of diameter) and measured; 20 -30 measurements were taken per treatment and day. The instrument was calibrated using a white tile $\left(\mathrm{L}^{*}=93.97\right.$, $a^{*}=\grave{A} 0.88$ and $\left.b^{*}=1.21\right)$ and a green tile $\left(L^{*}=56.23\right.$, $a^{*}=\hat{A} 21.85, b^{*}=8.31$ ) standards. The $L^{*}$ parameter (lightness index scale) range from 0 (black) to 100 (white). The $a^{*}$ parameter measures the degree of red $(+a)$ or green $\left(\hat{A} a^{*}\right)$ colour and the $b^{*}$ parameter measures the degree of yellow $(+b)$ or blue (À $\left.b^{*}\right)$ colour. The CIE $L^{*} a^{*} b^{*}$ parameters were converted to Hue $\left(\arctan b^{*} / a^{*}\right)$, Chroma $\left(a_{2}+b_{2}\right)_{1 / 2}$ and total colour difference $\left(D E=\left[\left(L_{f} \hat{A} L_{i}\right)_{2}+\left(a_{\mathrm{f}} \hat{A} a_{i}\right)_{2}+\left(b_{f} \hat{A} b_{i}\right)_{2}\right]_{1 / 2}\right)$, where: $L$ i: initial luminosity, $L$ f: final luminosity, $a$ f: $a^{*}$ value at final time, $a_{i}$ : $a^{*}$ value at initial time, $b \mathrm{f}: b^{*}$ at final time and $b$ : the value $b^{*}$ at initial time.

\subsubsection{Browning-related enzymes: peroxidase (POD)}

E.C.1.11.1.7 and polyphenol oxidase (PPO) E.C.1.10.3.1. Both enzymes were assayed in homogenates prepared as follows: $10 \mathrm{~g}$ of vegetable was placed in a polytron homogeniser (Polytron model PT 3000) in a $1: 2(\mathrm{w}: \mathrm{v})$ ratio with $0.5 \mathrm{M}$ phosphate buffer pH 6.5 containing 50 g/L polyvinylpyrrolidone. Homogenisation was carried out two times at $4-\mathrm{C}$, and $5500 \mathrm{rpm}$, for 1 min each time with a break of 3 min between homogenisations in order to avoid excess heating of the sample. The homogenate was then centrifuged at 12,720 Âg for 30 min at $4-C$ and supernatant filtered through one layer of crepe bandage. The resulting crude extract was used without further purification. All the extracts were stored at $4-\mathrm{C}$ in the dark and used immediately.
PPO activity was assayed spectrophotometrically by a modified method based on Galeazzi, Sgarbieri, and Constantinides (1981) and Tan and Harris (1995). The reaction mixture contained $0.1 \mathrm{~mL}$ crude extract and $2.9 \mathrm{~mL}$ substrate solution ( $0.02 \mathrm{~mol} / \mathrm{L}$ catechol in $0.05 \mathrm{~mol} / \mathrm{L}$ phosphate buffer, $\mathrm{pH} 6.5)$. The rate of catechol oxidation was followed at $400 \mathrm{~nm}$ for 2 $\min$ at $25-\mathrm{C}$. An enzyme activity unit was defined as an increase of 0.1 in absorbance per minute. The reaction mixture contained $0.2 \mathrm{~mL}$ of extract and $2.7 \mathrm{~mL}$ of $0.05 \mathrm{M}$ phosphate buffer $\mathrm{pH} 6.5$ containing $100 \mathrm{AL}$ of hydrogen peroxide $(1 \mathrm{~mL} / \mathrm{L}$ $\mathrm{v} / \mathrm{v}$ ) as oxidant and $200 \mathrm{AL}$ of p-phenylendiamine as hydrogen donor. The oxidation of p-phenylendiamine was monitored at $485 \mathrm{~nm}$ and $25-\mathrm{C}$. An enzyme activity unit was defined as an increment of 0.1 in absorbance per minute.

2.3.1.6. Texture analysis. Texture properties of lettuce and carrots were assessed using an Instron texture analyser (Instron 4302 Universal Testing Machine, Canton MA, USA). A 500 N load cell was attached. For lettuce a Kramer shear cell with an 8 blade probe attached to the instrument was used. The speed setting for the experiment was $100(\mathrm{~mm} / \mathrm{min})$ and maximum load was reported $(\mathrm{kN} / \mathrm{g})$. The tests were performed only on photosynthetic tissue. Different vascular orientation respect to the blades of the Kramer was used (perpendicular and parallel). The carrot was measured with a puncture test performed using a $1 \mathrm{~cm}$ diameter aluminium probe with star-shape section. The speed setting was $1000(\mathrm{~mm} / \mathrm{min})$ and the maximum load reported ( $\mathrm{kN} / \mathrm{g})$. Data were analysed with the Instron series IX software for Windows. Initially, several whole lettuce heads were tested, to examine variability within the product.

2.3.1.7. Sensory analysis. Sensory analysis was performed for lettuce and carrot over 10 days of storage time by a panel of untrained members with an age range of $25-40$ years. Fresh appearance, browning for lettuce and whiteness for carrots, texture, off-odour and general acceptability of samples were scored on a hedonic scale of 1 to 10 . The applied cut off for the different attributes was fixed at 5 and scores above 5 indicates unacceptable sample. The sensory panel was selected from among the members of the department and the evaluation was carried out in the sensory evaluation laboratory. Data analysis was carried out with Compusense $\backslash$ Five software (Release 4.4, Ontario, Canada).

\subsubsection{Microbial markers}

Microbiology analyses were carried out on the samples before and after the treatment at regular intervals through the storage period. $25 \mathrm{~g}$ of vegetable were blended in $225 \mathrm{~mL}$ of peptone saline with a Stomacher circulator homogenizer. Enumeration and differentiation of microorganism were carried out as follows: mesophilic bacteria were quantified at $30-\mathrm{C}$ in plate count agar (PCA) over $72 \mathrm{~h}$. Psychrotrophic bacteria were quantified in plate count agar (PCA) at 4 -C over $72 \mathrm{~h}$. Enumeration of lactic acid bacteria was carried out using DeMan rogosa sharpe agar (MRS) at $35-C$ over $48 \mathrm{~h}$. The results were expressed as $\log _{10}$ colony forming units per gram (CFU/g). Due to the huge variability for the leafy products 
(lettuce) the samples for microbiological assays were taken from the top of the lettuce leaf.

\subsubsection{Nutritional markers}

Total carotenoids were extracted in dark conditions by homogenizing carrot tissue $(5 \mathrm{~g})$ with $30 \mathrm{~mL}$ of an acetone/ ethanol (50:50 v : v) solution, containing $200 \mathrm{mg} / \mathrm{L}$ of butylated hydroxytoluene (BHT). The homogenate was filtered and washed with acetone/ethanol solvent until colourless. Filtrate was adjusted to $100 \mathrm{~mL}$ volume with acetone/ethanol. An aliquot was placed in a $1 \mathrm{~cm}$ cuvette and its absorbance measured at $470 \mathrm{~nm}$. Total carotenoids ( $\mathrm{mg} / \mathrm{g}$ of sample) were calculated as described by Gross (1991). Ascorbic acid determination was carried out according to the 2,6,-dichlorolindophenol method recommended by AOAC (1995) for the analysis of Vitamin $\mathrm{C}$ in fruits and juices. The results were expressed as mg ascorbic acid in g of sample.

\subsection{Statistical analysis}

Data were analysed using multi analysis of variance (MANOVA) using Statgraphics software (version 2.1; Statistical Graphics Co., Rockville, USA) for different washing treatments. Analysis of variance one-way (ANOVA) has been used to analyse each treatment over storage. In the case of significant differences LSD range test $(p<0.05)$ was used.

\section{Results and Discussion}

\subsection{Quality markers}

\subsubsection{Headspace gas composition changes}

Fig. 1 shows the changes in headspace gas composition (oxygen and carbon dioxide levels) in fresh-cut vegetables bags (lettuce and carrots) during storage.

Fresh-cut lettuce did not show a significant effect of washing treatment $(p<0.05)$ since all the samples exhibited the same behaviour during storage (Fig. 1 I). Slight differences were observed between treatments though not significant. Oxygen decreased from atmospheric concentration (packaging conditions) to values around $14 \%$ after the first day of storage (Fig. 1 I). This rapid decrease reflected the high respiration rate caused by the stress the minimal processing procedures had on the vegetable (Surjadinata \& Cisneros-Zevallos, 2003). After day 1 , oxygen levels decreased slowly reaching values between $10 \%$ and $13 \%$ at day 10 . Carbon dioxide showed the opposite behaviour to oxygen, increasing significantly $(p<0.05)$ during storage, reaching final concentrations of around $5 \%$ to $7 \%$. A
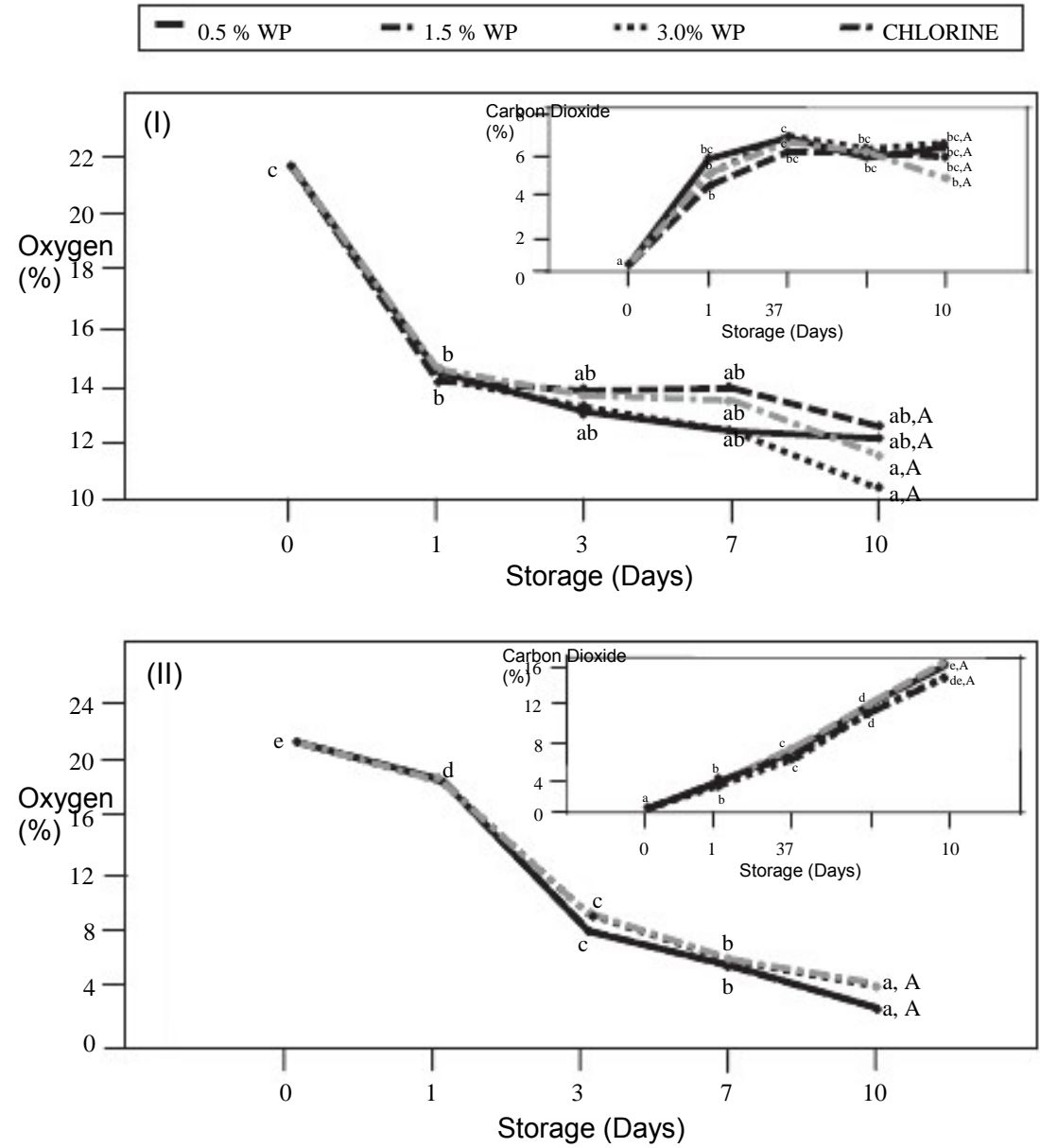

Fig. 1. Effect of washing treatments (120 ppm chlorine and $0.5 \%, 1.5 \%$ and $3 \%$ whey permeate (WP)) on the oxygen and carbon dioxide headspace gas (\%) in freshcut lettuce (I) and sliced carrot (II) package monitored over 10 days storage at 4 -C. 
hypoxic atmosphere was not reached at the end of the storage period. Such conditions will minimise fermentative processes which might cause the formation of acetaldehyde and the appearance of off-flavour compounds (Kays, 1991). Differences between treatments were not found, the whey permeate did not produce any reduction in respiration rate compared to chlorine treated samples (Fig. 1 I).

In sliced carrot packages (Fig. 1 II) levels of oxygen and carbon dioxide did not show significant differences between treatments. Since respiration causes oxygen consumption and carbon dioxide production, the concentrations of these gases will have an inverse relationship throughout storage. The levels of oxygen at the end of storage were below $5 \%$ and carbon dioxide levels had risen to be above $15 \%$. The oxygen levels at the end of storage were lower than in fresh-cut lettuce. This higher respiration rate for carrot could be due to the stress produced by peeling of the vegetable. After peeling cells that are close to the site of the injury strengthen their cells walls by the secretion of additional structural components, like lignin, which causes an activation of metabolism and consequently a higher respiration rate. However, the levels at the end of storage are considered acceptable for sliced carrots (Fonseca, Oliveira, Brecht, \& Chau, 1999).

\subsection{2. $\mathrm{pH}$ measurement}

Immediately after the treatment fresh-cut lettuce samples washed with chlorine had higher $\mathrm{pH}$ values (6.12) than samples treated with WP (5.83 to 5.96). Lower concentrations of whey permeate had significant higher $\mathrm{pH}$ (5.96) values than samples treated with high WP concentrations (5.83). Sliced carrots showed the same behaviour. The samples treated with chlorine had higher $\mathrm{pH}$ (5.9) after treatment than samples treated with whey permeate (5.8 to 5.78). As with the lettuce, sliced carrots washed with lower concentrations of whey permeate presented significant higher $\mathrm{pH}$ (5.8) values than samples treated with high WP concentrations (5.78). The $\mathrm{pH}$ values increased significantly during the storage in all the samples for both vegetables showing higher $\mathrm{pH}$ values the samples treated with chlorine than samples treated with whey permeate. The lowest $\mathrm{pH}$ values appeared in samples washed with $3 \% \mathrm{WP}$. The increases in $\mathrm{pH}$ during the storage are associated with bacterial growth. For that reason, 3\% WP might control better the microbial growth than chlorine or lower WP concentrations (0.5\% and $1.5 \%$ ). Microbiological results (shown below) confirmed this, showing samples treated with 3\% WP the lowest microbial load. The relatively high oxygen concentration in all the packages during all the storage (Fig. 1) might have controlled fermentative process (growth LAB). Decreases in the $\mathrm{pH}$ were not observed during all the storage at any treatment and for both vegetables, which might be associated with a good maintenance quality of the fresh-cut products (Bolin \& Huxoll, 1991). after processing and throughout storage. The loss of water is a natural process of the catabolism of fresh-cut vegetables, and is attributed to the respiration and other senescence-related metabolic processes during storage (Watada \& Qui, 1999). This loss in water was not influenced by the washing treatment.

\subsubsection{Colour changes}

Fresh-cut lettuce showed significant variation in luminosity during storage. The luminosity decreased significantly ( $p<0.05$ ), a change that might be associated with browning oxidation (Fig. 2 I). There were no differences in $L^{*}$ values between treatments, although samples treated with chlorine showed higher luminosity at day 1 (Fig. 2 I), perhaps due to the bleaching effect of chlorine on the tissue after the treatment.

The parameter $\mathrm{a}^{*}$ showed significant differences between treatments. Lettuce treated with $3 \% \mathrm{WP}$ showed higher $(p<0.05)$ initial $a^{*}$ values compared to the rest of the treatments. However, $a^{*}$ remained constant throughout storage.

By contrast, samples treated with chlorine had lower initial $a^{*}$ values but had higher values by the end of storage (data not shown). Lettuce treated with $0.5 \%$ and $1.5 \%$ WP showed intermediate behaviour. Differences in $b^{*}$, Hue and Chroma were not observed between treatments or during storage.

Significant differences in total colour change $(p<0.05)$ were observed between treatments. Samples treated with chlorine had the greatest changes in colour (Fig. 2 I). This may be related to their higher luminosity (L) values at day 1 and the higher variation in $a^{*}$ values observed throughout storage for this treatment. The highest colour changes were observed between day 3 and 7 for all the samples treated with WP, while chlorine treated samples gave higher but equal changes for the three time periods (Fig. 2 I). The sensory panel observed changes in colour during storage but differences between treatments were not detectable (Table 3). No correlation between colorimeter and sensory panel results was observed. This may be due to the higher accuracy of instrumental measurements compared to the visual evaluation by the sensory panel combined with the heterogeneous nature of the vegetable.

Sliced carrot luminosity showed a significant $(p<0.05)$ increase during storage (Fig. 2 II), probably due to the appearance of surface whiteness. This quality alteration has been associated with the formation of lignin as a protection reaction to the processing of the sample (peeling). Chlorine and 3\% WP samples showed the highest luminosity values (Table 3). The appearance of whiteness was also observed by the sensory panel, giving the highest whitening scores to the samples treated with chlorine and 3\% WP.

Other parameters such as $a^{*}, b^{*}$, hue and chroma, did not show significant differences between treatments or significant changes during storage. The highest values of total colour change (Fig. 2 II) were observed in samples treated with $0.5 \%$ WP. This may be due to the high luminosity increase seen during storage for this treatment.

\subsubsection{Dry matter}

The water loss of the samples increased significantly ( $p<0.05$ ) during storage for both vegetables (data not shown). This was expected since fresh-cut vegetables usually lose water

\subsubsection{Browning-related enzymes}

PPO and POD enzymes were evaluated for fresh-cut lettuce and sliced carrots throughout storage. 


\section{$0.5 \%$ WP $\square 1.5 \%$ WP $\square 3 \%$ WP $\square$ Chlorine}
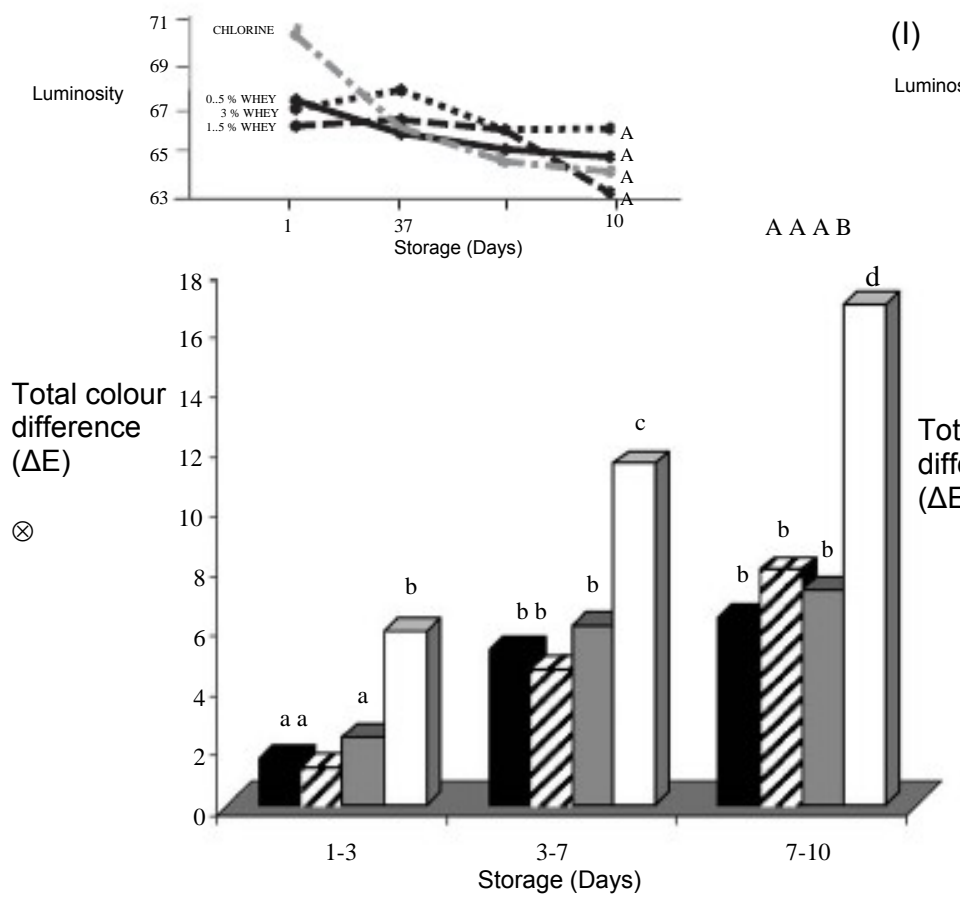

(I)

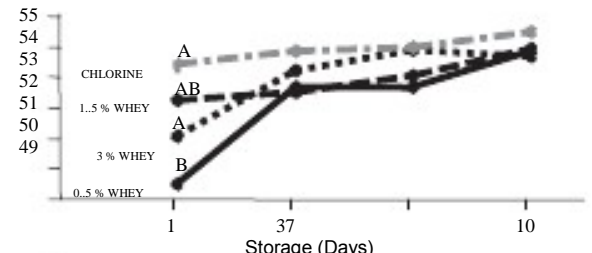

(II)

A A A B

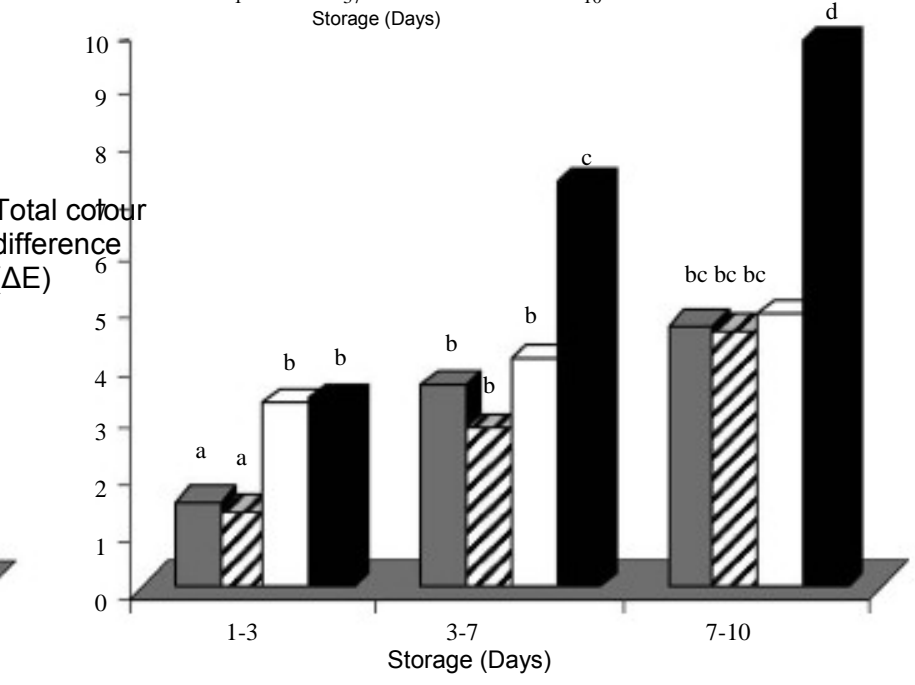

Fig. 2. Total colour difference and Luminosity (CIE L*a*b*) during storage at $4-\mathrm{C}$ for fresh-cut lettuce and carrots treated with $120 \mathrm{ppm}$ chlorine and $0.5 \%, 1.5 \%$ and $3 \%$ whey permeate (WP) as washing treatments.

A significant decrease in PPO activity was observed for lettuce during storage. In fresh-cut lettuce significant differences $(p<0.05$ ) were observed between treatments (Table 1 ). $3 \%$ WP showed the lowest PPO values followed by $1.5 \% \mathrm{WP}$, chlorine and $0.5 \% \mathrm{WP}$.
In sliced carrots an increase in PPO activity was observed during storage $(p<0.05)$. Differences between treatments were found between chlorine and the three WP treatments. Chlorine samples showed the highest PPO values throughout storage for both vegetables. This behaviour might indicate an inhibitory

Table 1

Effect of storage and treatment (chlorine " 120 ppm and whey permeate (WP) at $0.5 \%, 1.5 \%$ and $3 \%$ ) on polyphenol oxidase (PPO) and peroxidase (POD) activity expressed in fresh-cut lettuce and sliced carrots stored at $4-\mathrm{C}$ for 10 days

\begin{tabular}{|c|c|c|c|c|c|c|c|}
\hline \multirow[t]{3}{*}{ Enzyme } & \multirow[t]{3}{*}{ Vegetable } & \multirow[t]{3}{*}{ Treatments } & \multirow{3}{*}{$\begin{array}{l}\text { Differences between } \\
\text { treatments ( } p \text { value) }\end{array}$} & \multicolumn{4}{|c|}{ Enzymatic activity (units activity g-1 vegetable) } \\
\hline & & & & \multicolumn{4}{|l|}{ Storage (days) } \\
\hline & & & & 1 & 3 & 7 & 10 \\
\hline \multirow[t]{10}{*}{ PPO } & \multirow[t]{5}{*}{ Lettuce } & $0.5 \% \mathrm{WP}$ & $\mathrm{D}$ & 34773 T 1096d & 35063 T 865d & 35040 T 193d & 18670 T 257a \\
\hline & & $1.5 \% \mathrm{WP}$ & $\mathrm{B}$ & $34612 \mathrm{~T} 1200_{\mathrm{d}}$ & 24598 T 329b & 30121 T 46c & 19481 T 646a \\
\hline & & $3 \% \mathrm{WP}$ & A & 20817 T 92a & 20414 T 394a & 20383 T 90a & 20980 T 240a \\
\hline & & Chlorine & $\mathrm{C}$ & 27905 T 33b & 38818 T 214e & 29539 T 45c & 21256 T 704a \\
\hline & & $0.5 \% \mathrm{WP}$ & A & 7115 T 604b & 15390 T $1669 c$ & 16229 T 2138c & $14002 \mathrm{~T} 1100_{\mathrm{c}}$ \\
\hline & \multirow[t]{5}{*}{ Carrot } & $1.5 \% \mathrm{WP}$ & $\mathrm{A}$ & 4976 T 934a & 14957 T 4021c & 13213 T 1186 c & 20197 T 1160d \\
\hline & & $3 \%$ WP & A & 6601 T170ab & 13345 T 1895c & 13394 T 1218c & 18492 T 603cd \\
\hline & & Chlorine & $\mathrm{B}$ & 5520 T 509a & 20129 T 1733d & 16545 T 2725c & 20343 T 1451d \\
\hline & & $0.5 \% \mathrm{WP}$ & $\mathrm{BC}$ & 5105 T 755ab & 8092 T $62 c$ & 12130 T 828d & $22240 \mathrm{~T} 1621 \mathrm{e}$ \\
\hline & & $1.5 \% \mathrm{WP}$ & A & 4229 T 282a & 6945 T 25b & 8698 T 262c & 19863 T 757e \\
\hline \multirow[t]{6}{*}{ POD } & \multirow[t]{5}{*}{ Lettuce } & $3 \% \mathrm{WP}$ & $\mathrm{AB}$ & 4499 T 302a & 6557 T 90b & 10562 T 435cd & $21091 \mathrm{~T} 1174_{\mathrm{ef}}$ \\
\hline & & Chlorine & $\mathrm{C}$ & 6490 T 551b & 8421 T 59c & 12385 T 536d & 19882 T $1137 \mathrm{e}$ \\
\hline & & $0.5 \%$ WP & A & 2611 T 326a & 3113 T 346b & 3397 T 411bc & 2643 T 235ab \\
\hline & & $1.5 \% \mathrm{WP}$ & $\mathrm{A}$ & 2915 T 482b & 2717 T 268b & 3123 T 91b & 2441 T121a \\
\hline & & $3 \% \mathrm{WP}$ & A & 2825 T 261b & 2643 T 289b & 2910 T 139b & 2806 T 306ab \\
\hline & Carrot & Chlorine & $\mathrm{B}$ & 3443 T 242b & 3165 T 339b & 4082 T 287c & 2394 T 72a \\
\hline
\end{tabular}


effect of whey permeate on the PPO activity. The differences in PPO values for both vegetables were not reflected in the sensory analysis data where the panel could not find differences in visual browning between treatments. Thus, while samples treated with 3\% WP had the lowest levels of browning-related enzymes this did not correlate with a detectable difference in visual browning over a 10 day storage period. It is possible that over such a short storage period those visual browning changes are too small to be appreciated by the human eye.

The data for POD showed that samples treated with WP had lower activity values compared to chlorine treated samples. This might reflect a higher antioxidant capacity of WP (Table 1). Differences in POD activity were not observed for different WP concentrations in sliced carrots. However, in fresh-cut lettuce higher concentrations of WP had higher antioxidant capacity.

\subsubsection{Textural analysis}

The instrumental measurement of lettuce texture is difficult due to the high variability of the product, which contains two different types of tissue (vascular and photosynthetic). The tissues are not always easily identified or segregated. Measurement is made more difficult by the variable orientation of the tissues relative to the instrument for texture measurement. To reduce this variability all the textural experiments were carried out using a segregated sample of photosynthetic tissue from the top part of the lettuce head.

Higher maximum load was needed for samples with the vascular packages (fibres) placed perpendicular (0.0555 T $0.0017 \mathrm{kN} / \mathrm{g}$ ) than for those placed parallel (0.0839 T 0.0016 $\mathrm{kN} / \mathrm{g}$ ) with respect to the blades of the Kramer shear cell. Significant differences in maximum load $(p<0.05)$ were observed for all treatments during storage when the tissue was placed in a parallel orientation (Table 2) and were not observed for the perpendicular placement. Maximum load increased from $0.045-0.050 \mathrm{kN} / \mathrm{g}$ (day 1) to $0.066-0.073 \mathrm{kN} /$ $\mathrm{g}$ (day 10). This increase in load could be related to an increase in tissue flexibility (loss of crispness). The loss of cell turgor (loss of moisture) can produce dehydration of the tissues and an increase in elasticity. Significant differences $(p<0.05)$ between treatments were not observed for any test condition (parallel and perpendicular orientation).

In sliced carrots, significant differences in maximum fracture load (puncture cell) could not be observed between treatments but an increase in load was observed at the end of storage (Table 2). The loss of turgor due to loss of water produces an increase in flexibility which probably reflects the higher maximum load needed to fracture the sample. The results for texture in lettuce and carrots were confirmed by the sensory panel which did not find differences between treatments although differences during storage were found (Table 3).

\subsubsection{Sensory analysis}

Sensory quality was analysed in fresh-cut lettuce and sliced carrots during storage. In lettuce, Table 3 , all the attributes decreased significantly $(p<0.05)$ during storage which is associated with a loss of quality. However, the values at the end of the storage (10 days) were higher than values considered acceptable (5.0) for all the attributes scored, with no significant differences between treatments. At day 1 the lowest scores for fresh appearance, browning and general acceptability were for the chlorine (Table 3). For most of the parameters evaluated between day 3 and 7 a significant quality deterioration was observed.

In sliced carrots the initial sensory scores were lower than the values for fresh-cut lettuce. This is related to the type of vegetable; carrot loses quality more quickly than lettuce due to the stress produced as a result of the peeling and slicing steps. Low WP concentrations ( $0.5 \%$ and $1.5 \%$ ) resulted in better sensorial scores than 3\% WP and chlorine. These differences between treatments were mostly observed for sensorial parameters related to the visual aspects of the sample, i.e. fresh appearance, surface whiteness and general acceptability. Texture and off-odours did not show differences between treatments. The lack of off-flavours at the end of storage was favoured by non hypoxic oxygen and carbon dioxide levels in lettuce and carrots (Fig. 1).

Table 2

Effect of storage and treatment (chlorine $" 120 \mathrm{ppm}$ and whey permeate (WP) at $0.5 \%, 1.5 \%$ and $3 \%$ ) on the maximum load (kN)/g of vegetable in fresh-cut lettuce and sliced carrots stored at $4-\mathrm{C}$ for 10 days

\begin{tabular}{|c|c|c|c|c|c|c|}
\hline \multicolumn{7}{|c|}{ Max. Load (kN gÀ 1 sample) } \\
\hline \multirow[t]{2}{*}{ Vegetable } & \multirow[t]{2}{*}{ Treatment } & \multirow{2}{*}{$\begin{array}{l}\text { Differences between } \\
\text { treatments ( } p \text { value) }\end{array}$} & \multicolumn{4}{|l|}{ Storage (days) } \\
\hline & & & 1 & 3 & 7 & 10 \\
\hline \multirow[t]{5}{*}{ Lettuce } & Chlorine & NS & 0.05 T 0.003ab & 0.061 T $0.007 \mathrm{~b}$ & 0.054 T 0.003ab & 0.066 T $0.008 \mathrm{~b}$ \\
\hline & $0.5 \%$ WP & NS & 0.046 T $0.003 \mathrm{a}$ & 0.053 T $0.007 \mathrm{ab}$ & $0.054 \mathrm{~T} 0.002 \mathrm{ab}$ & $0.061 \mathrm{~T} 0.002 \mathrm{~b}$ \\
\hline & $1.5 \%$ WP & NS & 0.050 T 0.003ab & 0.062 T $0.008 \mathrm{~b}$ & $0.054 \mathrm{~T} 0.003 \mathrm{ab}$ & 0.052 T $0.010 \mathrm{ab}$ \\
\hline & $3 \% \mathrm{WP}$ & NS & 0.045 T $0.003 \mathrm{a}$ & 0.060 T $0.011 \mathrm{~b}$ & 0.057 T $0.002 \mathrm{ab}$ & $0.073 \mathrm{~T} 0.011 \mathrm{~b}$ \\
\hline & Chlorine & NS & 0.051 T $0.002 \mathrm{a}$ & $0.072 \mathrm{~T} 0.001 \mathrm{~b}$ & 0.054 T $0.021 \mathrm{ab}$ & $0.068 \mathrm{~T} 0.002 \mathrm{~b}$ \\
\hline \multirow[t]{3}{*}{ Carrot } & $0.5 \%$ WP & NS & 0.052 T $0.005 \mathrm{a}$ & $0.067 \mathrm{~T} 0.002 \mathrm{~b}$ & 0.060 T $0.021 \mathrm{ab}$ & 0.069 T $0.002 \mathrm{~b}$ \\
\hline & $1.5 \% \mathrm{WP}$ & NS & 0.060 T $0.001 \mathrm{ab}$ & 0.064 T $0.002 \mathrm{ab}$ & 0.059 T $0.001 \mathrm{ab}$ & 0.068 T $0.002 \mathrm{~b}$ \\
\hline & $3 \%$ WP & NS & $0.061 \mathrm{~T} 0.001 \mathrm{ab}$ & 0.064 T $0.002 \mathrm{ab}$ & $0.068 \mathrm{~T} 0.001 \mathrm{~b}$ & 0.069 T $0.001 \mathrm{~b}$ \\
\hline
\end{tabular}

*Values designated by the same letters are not significantly different $(p<0.05)$. Lower case letters are used for comparisons during storage. NS is no significant differences. 
Sensory evaluation of fresh-cut lettuce and carrots packaged at $4-\mathrm{C}$ and sanitized with chlorine (120 ppm) and whey permeate (WP) at $0.5 \%, 1.5 \%$ and $3 \%$ over 10 storage days

\begin{tabular}{|c|c|c|c|c|c|c|c|c|c|c|c|}
\hline \multirow[t]{3}{*}{ Attributtes } & \multirow[t]{3}{*}{ Treatments } & \multirow{2}{*}{\multicolumn{2}{|c|}{$\begin{array}{l}\text { Differences between Treatments } \\
\text { ( } p \text { values) }\end{array}$}} & \multicolumn{8}{|l|}{ Storage (days) } \\
\hline & & & & \multicolumn{2}{|l|}{1} & \multicolumn{2}{|l|}{3} & \multicolumn{2}{|l|}{7} & \multicolumn{2}{|l|}{10} \\
\hline & & Lettuce & Carrot & Lettuce & Carrot & Lettuce & Carrot & Lettuce & Carrot & Lettuce & Carrot \\
\hline \multirow{5}{*}{$\begin{array}{l}\text { Fresh } \\
\text { appearance }\end{array}$} & $0.5 \%$ WP & \multirow[t]{5}{*}{ NS } & B & $8.60 \mathrm{~T} 0.33 \mathrm{~b}$ & $7.30 \mathrm{~T} 1.01 \mathrm{c}$ & 8.71 T 0.36b & $6.91 \mathrm{~T} 0.77 \mathrm{bc}$ & $6.44 \mathrm{~T} 0.37 \mathrm{a}$ & $6.00 \mathrm{~T} 1.01 \mathrm{~b}$ & 5.62 T 0.33a & 5.34 Т $0.86 \mathrm{~b}$ \\
\hline & $1.5 \%$ WP & & $\begin{array}{l}\mathrm{D} \\
\mathrm{B}\end{array}$ & 8.70 T $0.46 \mathrm{~b}$ & $7.54 \mathrm{~T} 1.02 \mathrm{c}$ & 7.93 T 0.51 & $6.86 \mathrm{~T} 1.17 \mathrm{bc}$ & 6.46 T $0.52 \mathrm{a}$ & $6.14 \mathrm{~T} 1.25 \mathrm{~b}$ & 5.96 T $0.46 \mathrm{a}$ & $5.32 \mathrm{~T} 0.87 \mathrm{a}$ \\
\hline & $3.0 \% \mathrm{WP}$ & & A & 9.06 T $0.33 \mathrm{~b}$ & $7.19 \mathrm{~T} .25 \mathrm{bc}$ & 8.81 T $0.36 \mathrm{~b}$ & $6.98 \mathrm{~T} 0.87 \mathrm{bc}$ & 6.36 T $0.38 \mathrm{a}$ & $4.48 \mathrm{~T} 1.11 \mathrm{a}$ & $6.12 \mathrm{~T} 0.33 \mathrm{a}$ & 4.23 T $0.55 \mathrm{a}$ \\
\hline & Chlorine & & A & $8.29 \mathrm{~T} 0.41 \mathrm{~b}$ & $7.13 \mathrm{~T} 1.23 \mathrm{bc}$ & $8.57 \mathrm{~T} 0.45 \mathrm{~b}$ & $6.82 \mathrm{~T} 1.11 \mathrm{bc}$ & $6.69 \mathrm{~T} 0.47 \mathrm{a}$ & $4.64 \mathrm{~T} 0.90 \mathrm{a}$ & $6.13 \mathrm{~T} 0.41_{\mathrm{a}}$ & $4.24 \mathrm{~T} 0.55 \mathrm{a}$ \\
\hline & $0.5 \%$ WP & & B & 9.90 T $0.39 \mathrm{~b}$ & $8.66 \mathrm{~T} 0.73 \mathrm{~d}$ & $8.90 \mathrm{~T} 0.43 \mathrm{c}$ & $7.67 \mathrm{~T} 1.64 \mathrm{c}$ & 7.17 T $0.44 a$ & $5.76 \mathrm{~T} 1.10 \mathrm{~b}$ & $6.27 \mathrm{~T} 0.39 \mathrm{a}$ & 4.87 T $0.99 a$ \\
\hline \multirow{4}{*}{$\begin{array}{l}\text { Browning/ } \\
\text { whiteness }\end{array}$} & $1.5 \%$ WP & \multirow[t]{4}{*}{ NS } & $\mathrm{B}$ & 8.99 T $0.45 \mathrm{~b}$ & 8.00 T $1.58 c$ & $8.61 \mathrm{~T} 0.49 \mathrm{~b}$ & $7.25 \mathrm{~T} 1.68 \mathrm{c}$ & 7.10 T $0.51 \mathrm{a}$ & $5.94 \mathrm{~T} 1.10 \mathrm{~b}$ & 6.24 T 0.45a & 4.99 T $1.20 \mathrm{a}$ \\
\hline & $3.0 \%$ WP & & $\mathrm{AB}$ & $9.34 \mathrm{~T} 0.45 \mathrm{~b}$ & $8.17 \mathrm{~T} 1.49 \mathrm{~cd}$ & $9.14 \mathrm{~T} 0.50 \mathrm{~b}$ & $8.07 \mathrm{~T} 1.25 \mathrm{c}$ & 7.11 T $0.50 \mathrm{a}$ & $4.74 \mathrm{~T} 0.77 \mathrm{a}$ & $6.45 \mathrm{~T} 0.45 \mathrm{a}$ & $4.33 \mathrm{~T} 1.38 \mathrm{a}$ \\
\hline & Chlorine & & $\mathrm{A}$ & $7.89 \mathrm{~T} 0.46 \mathrm{ab}$ & $7.01 \mathrm{~T} 3.10 \mathrm{bc}$ & $8.69 \mathrm{~T} 0.51 \mathrm{~b}$ & $7.53 \mathrm{~T} 1.68 \mathrm{bc}$ & 7.97 T $0.52 \mathrm{ab}$ & 4.86 T $0.60 \mathrm{a}$ & $7.01 \mathrm{~T} 0.46 \mathrm{a}$ & 4.78 T $0.88 \mathrm{a}$ \\
\hline & $0.5 \%$ WP & & NS & $9.13 \mathrm{~T} 0.37 \mathrm{~b}$ & $8.59 \mathrm{~T} 0.81 \mathrm{c}$ & $8.58 \mathrm{~T} 0.41 \mathrm{~b}$ & $8.36 \mathrm{~T} 0.88 \mathrm{c}$ & 6.67 T $0.42 \mathrm{a}$ & $6.51 \mathrm{~T} 2.23 \mathrm{~b}$ & 6.32 T $0.37 \mathrm{a}$ & 4.82 T $0.93 \mathrm{a}$ \\
\hline \multirow{5}{*}{ Texture } & $1.5 \%$ WP & \multirow{5}{*}{\multicolumn{2}{|c|}{ NS }} & 8.85 T $0.40 \mathrm{~b}$ & $8.06 \mathrm{~T} 1.81 \mathrm{c}$ & $8.72 \mathrm{~T} 0.44 \mathrm{~b}$ & $8.08 \mathrm{~T} 1.14 \mathrm{c}$ & $6.74 \mathrm{~T} 0.45 \mathrm{a}$ & 6.77 T $1.79 \mathrm{~b}$ & 6.34 T $0.40 \mathrm{a}$ & 4.63 T $1.06 \mathrm{a}$ \\
\hline & $3.0 \%$ WP & & & $8.65 \mathrm{~T} 0.40 \mathrm{~b}$ & $8.49 \mathrm{~T} 1.30 \mathrm{c}$ & 8.50 T $0.44 \mathrm{~b}$ & $8.31 \mathrm{~T} 0.97 \mathrm{c}$ & 6.96 T $0.45 \mathrm{a}$ & $6.73 \mathrm{~T} 1.90 \mathrm{~b}$ & $6.34 \mathrm{~T} 0.40 \mathrm{a}$ & 4.79 Т $0.89 \mathrm{a}$ \\
\hline & Chlorine & & & $8.92 \mathrm{~T} 0.41 \mathrm{~b}$ & $7.89 \mathrm{~T} 2.21 \mathrm{c}$ & $8.48 \mathrm{~T} 0.45 \mathrm{~b}$ & $8.19 \mathrm{~T} 1.23 \mathrm{c}$ & 6.60 T $0.46 \mathrm{a}$ & $6.64 \mathrm{~T} 1.93 \mathrm{~b}$ & $6.25 \mathrm{~T} 0.41 \mathrm{a}$ & 4.84 T $0.94 \mathrm{a}$ \\
\hline & $0.5 \%$ WP & & & $9.46 \mathrm{~T} 0.19 \mathrm{c}$ & $9.26 \mathrm{~T} 0.29 \mathrm{cc}$ & 9.04 T 0.20 & $8.87 \mathrm{~T} 0.79 \mathrm{~b}$ & 8.90 T $0.21 \mathrm{~b}$ & 8.73 T $0.43 \mathrm{~b}$ & 7.52 T $0.18 \mathrm{a}$ & $6.54 \mathrm{~T} 1.19 \mathrm{a}$ \\
\hline & $1.5 \%$ WP & & & $9.42 \mathrm{~T} 0.28 \mathrm{c}$ & 9.19 T $0.36 \mathrm{~b}$ & 9.08 T $0.31 \mathrm{bc}$ & $8.77 \mathrm{~T} 0.90 \mathrm{~b}$ & $8.37 \mathrm{~T} 0.32 \mathrm{~b}$ & $8.44 \mathrm{~T} 1.10 \mathrm{~b}$ & 7.10 T $0.28 \mathrm{a}$ & $6.08 \mathrm{~T} 1.42 \mathrm{a}$ \\
\hline \multirow{5}{*}{ Off-odours } & $3.0 \%$ WP & \multirow{5}{*}{ NS } & \multirow{5}{*}{ NS } & $9.24 \mathrm{~T} 0.23 \mathrm{bc}$ & $8.99 \mathrm{~T} 0.73 \mathrm{~b}$ & $8.93 \mathrm{~T} 0.26 \mathrm{~b}$ & $8.98 \mathrm{~T} 0.68 \mathrm{~b}$ & 8.81 T $0.27 \mathrm{~b}$ & $8.64 \mathrm{~T} 0.73 \mathrm{~b}$ & 7.16 T $0.23 \mathrm{a}$ & $6.11 \mathrm{~T} 1.20 \mathrm{a}$ \\
\hline & Chlorine & & & $9.10 \mathrm{~T} 0.21 \mathrm{bc}$ & 8.88 T $0.89 \mathrm{~b}$ & 9.01 T $0.23 \mathrm{bc}$ & 8.84 T $0.76 \mathrm{~b}$ & 8.94 T $0.24 b$ & $8.77 \mathrm{~T} 0.46 \mathrm{~b}$ & 7.68 T $0.21 \mathrm{a}$ & 6.50 T $1.26 \mathrm{a}$ \\
\hline & $0.5 \%$ WP & & & $9.20 \mathrm{~T} 0.41 \mathrm{~b}$ & $8.31 \mathrm{~T} 1.35 \mathrm{c}$ & $8.50 \mathrm{~T} 0.45 \mathrm{~b}$ & $7.77 \mathrm{~T} 1.30 \mathrm{c}$ & $6.22 \mathrm{~T} 0.47 \mathrm{a}$ & $5.80 \mathrm{~T} 0.68 \mathrm{~b}$ & $5.93 \mathrm{~T} 0.42 \mathrm{a}$ & 5.05 T $0.73 b$ \\
\hline & $1.5 \%$ WP & & & 8.10 T $0.50 \mathrm{~b}$ & $7.55 \mathrm{~T} 2.14 \mathrm{c}$ & $8.34 \mathrm{~T} 0.55 \mathrm{~b}$ & $7.87 \mathrm{~T} 1.22 \mathrm{c}$ & 5.80 T $0.57 \mathrm{a}$ & $6.01 \mathrm{~T} 0.71 \mathrm{~b}$ & $5.71 \mathrm{~T} 0.50 \mathrm{a}$ & $5.01 \mathrm{~T} 0.63 \mathrm{~b}$ \\
\hline & $3.0 \% \mathrm{WP}$ & & & $8.70 \mathrm{~T} 0.42 \mathrm{~b}$ & 7.94 T $1.97 \mathrm{c}$ & $8.65 \mathrm{~T} 0.55 \mathrm{~b}$ & $8.06 \mathrm{~T} 1.10 \mathrm{c}$ & 6.10 T $0.48 \mathrm{a}$ & $4.52 \mathrm{~T} 0.56 \mathrm{a}$ & $6.02 \mathrm{~T} 0.43 \mathrm{a}$ & 4.47 T $0.79 \mathrm{a}$ \\
\hline \multirow{3}{*}{$\begin{array}{l}\text { General } \\
\text { acceptability }\end{array}$} & Chlorine & \multirow[t]{3}{*}{ NS } & $\mathrm{C}$ & 7.88 T $0.46 \mathrm{ab}$ & $7.49 \mathrm{~T} 2.44 \mathrm{c}$ & $8.21 \mathrm{~T} 0.51 \mathrm{~b}$ & $7.66 \mathrm{~T} 1.46 \mathrm{c}$ & $6.53 \mathrm{~T} 0.53 \mathrm{a}$ & 4.59 T $0.71 \mathrm{a}$ & $6.24 \mathrm{~T} 0.46 \mathrm{a}$ & 4.26 Т $0.72 \mathrm{a}$ \\
\hline & & & BC & & & & & & & & \\
\hline & & & $\begin{array}{l}\mathrm{AB} \\
\mathrm{A}\end{array}$ & & & & & & & & \\
\hline
\end{tabular}

*Values designated by the same letter are not significantly different ( $p<0.05$ ). Lower case letters are used for comparisons during storage. NS is no significant differences.

1. Appearance ( $10=$ fresh appearance, $0=$ bad appearance).

. Browning/whiteness (10=browing/whiteness, $0=$ a lot browning/a lot whiteness).

3. Texture (10=very crispy texture, $0=$ soft texture)

6. Acceptability (10=good acceptability, $0=$ bad acceptability). 


\subsection{Microbial markers}

\subsubsection{Mesophilic counts}

The effect of WP $(0.5 \%, 1.5 \%$ and $3 \%)$ and chlorine (120 $\mathrm{ppm}$ ) washing treatments on the microbial load of packaged fresh-cut lettuce and carrots were monitored over 10 days storage at $4-C$. Large differences in microbial counts have been reported between batches of vegetable products. This has been attributed to numerous factors such as ambient conditions during harvest, the presence of soil accompanying the product or postharvest handling, etc. (Ponce et al., 2002). Another important factor is the natural variability of the product, especially in the case of leafy vegetables (lettuce). The degree of outer leaf removal and the part of the head (top or bottom) selected for analysis will also affect the microbial load measured. In order to minimise these effects, all the trials were carried out using vegetables from the same retailer during the same period of the year. The two large outer leaves of the lettuce heads were discarded and only the top part of the head was used.

In fresh-cut lettuce, mesophilic counts increased during storage for all the washing treatments. This increase was more obvious between days 3 and 7 (Fig. 3 I). Initial values in nontreated samples were similar ("105 CFU/g) to those reported by other authors (Kaneko et al., 1999; Ponce et al., 2002). All the treatments produced a reduction in the initial counts with respect to the non-treated lettuce. This reduction was signifi- cantly ( $p<0.05)$ more effective in samples treated with chlorine and 3\% WP (2 log CFU/g reduction) than in lettuce washed with $1.5 \% \mathrm{WP}$ (1 log CFU/g reduction) and $0.5 \% \mathrm{WP}$ (0.5 CFU/g reduction). From day 1 to 3 a significant increase in the microbial load counts was observed in all the treatments. No differences between treatments were found at the end of the storage (day 10) despite the initial differences described above. The values at the end of the storage were lower than the recommended (108 CFU/g) for consumer consumption (Debevere, 1996). Comparison between treatments ( $p$ value) showed than samples washed with $0.5 \%$ WP showed the lowest initial counts reduction and higher microbial load at the end of storage.

In sliced carrots (Fig. 3 II) initial mesophilic load was higher than in fresh-cut lettuce ("105-6 CFU/g) perhaps due to crosscontamination of the carrot during the manual peeling step. Other authors have observed increases of microbial counts for carrots (up to $1 \mathrm{log}$ ) after shredding, peeling, etc. (Allende, Aguayo, \& Artes, 2004). Samples treated with 3\% WP and' chlorine showed significantly $(p<0.05)$ better reduction in the mesophilic counts (2 log CFU/g) than samples treated with $0.5 \%$ and $1.5 \%$ WP (1 log CFU/g) immediately after the initial treatment (day 1). Chlorine and 3\% WP maintained lower counts during storage than $0.5 \%$ and $1.5 \%$ WP treatments (Fig. 3 ). At the end of the storage period the treated samples showed values lower than recommended for fresh-cut products (Debevere, 1996).

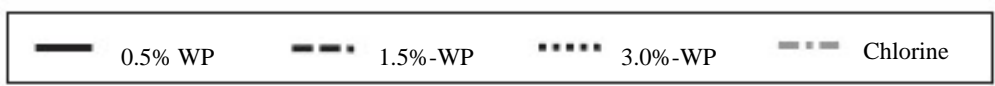

(I)
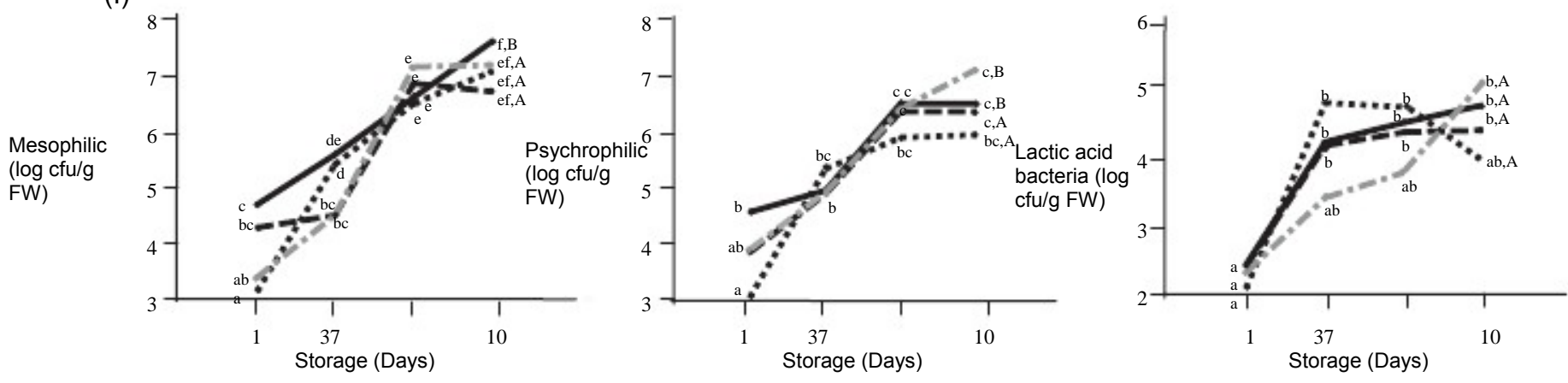

(II)
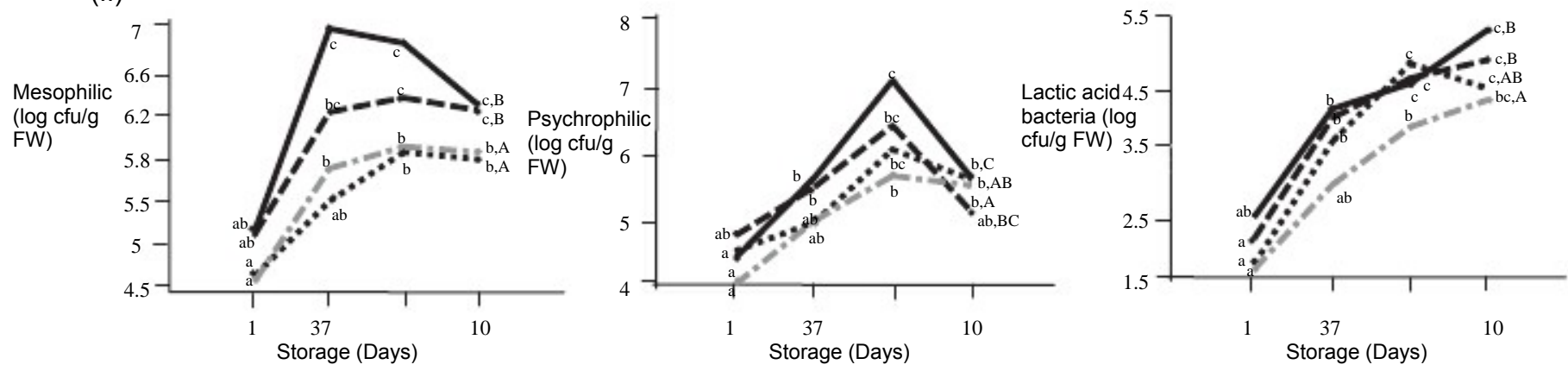

Fig. 3. Microbial load during storage of fresh-cut lettuce (I) and sliced carrots (II) following washed in 120 ppm of chlorine and $0.5 \%, 1.5 \%$ and $3 \%$ of whey permeate (WP) over 10 days storage at $4-\mathrm{C}$. 


\subsubsection{Psychrophilic counts}

Psychrophilic counts in lettuce at day 1 were reduced in all the treated samples (Fig. $3 \mathrm{I})$. The highest reduction (1.5 log $\mathrm{CFU} / \mathrm{g}$ ) was observed in samples treated with $3 \% \mathrm{WP}$ followed by samples treated with 1.5\% WP and chlorine (1 log CFU/g). The highest microbial load was observed in samples treated with $0.5 \%$ WP where the initial reduction was practically nonexistent. During the period from 3 to 7 days all the treatments showed similar growth until day 10 , where samples treated with $3 \%, 1.5 \%$ WP and chlorine had lower values than samples treated with $0.5 \%$ WP (Fig. 3).

In sliced carrots (Fig. 3 II) initial psycrophilic counts ("105-6 CFU/g) showed the most significant reduction for samples washed with chlorine followed closely by the of WP treatments. At day 3, chlorine and 3\% WP had similar values and maintained the values better than $1.5 \%$ and $0.5 \%$. At the end of storage all reached the same values.

\subsubsection{Lactic acid bacteria counts}

Lactic acid bacteria (LAB) were analysed in fresh-cut lettuce and sliced carrots during 10 days of storage (Fig. 3). In fresh-cut lettuce differences between treatments did not show (Fig. 3 I) meanwhile in sliced carrots chlorine and 3\% WP treatments showed a significant reduction in LAB growth compared to $0.5 \%$ and $1.5 \% \mathrm{WP}$.

High LAB loads are associated with fermentation processes (off-odours). However, controlled growth of these bacteria can have a positive antimicrobial effect on the vegetable due to their production of bacteriocins (Palleroni, 1984).

The antimicrobial capacity of whey permeate can be explained by a variety of factors. The most evident is the acid $\mathrm{pH}$ of the wash treatment which can have a direct effect on the initial microbial count reduction and on subsequent growth during storage. Another factor can be the presence of lactic acid, which can enter the cells in undissociated form. And finally, the presence of antibacterial peptides (caseinmacropeptide or bacteriocins) in the WP might contribute to its antimicrobial capacity (Clare \& Swaisgood, 2000; Kitts, 1993).

Although further investigations on pathogens are suggested, WP seems to be a good preservative method to

\begin{tabular}{|c|c|c|c|}
\hline $0.5 \%$ WP & $1.5 \% \mathrm{WP}$ & $\square$ 3\% WP & $\square$ Chlorine \\
\hline
\end{tabular}

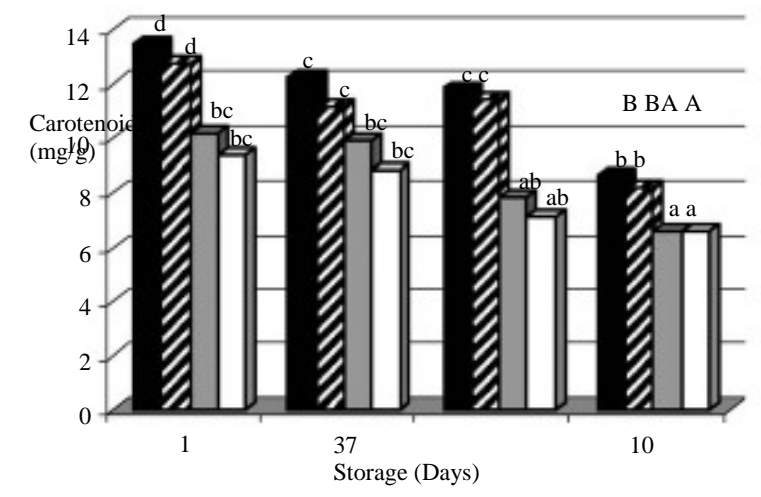

Fig. 4. Total carotenids (mg/g of sample) during storage of sliced carrots washed in $120 \mathrm{ppm}$ of chlorine and $0.5 \%, 1.5 \%$ and $3 \%$ of whey permeate (WP), over 10 storage days at $4-\mathrm{C}$.

control the growth of bacteria associated with vegetable product deterioration.

\subsection{Nutritional markers}

Ascorbic acid decreased during storage independently of the wash treatment, in agreement with the findings of other authors (Ihl, Aravena, Sheuermann, Uquiche, \& Bifani, 2003). The vitamin $C$ in fresh-cut lettuce treated with $3 \%$ WP had lower values than treatments with lower WP concentrations. Lettuce had similar ascorbic acid content when treated with chlorine to treatment with 3\% WP (Table 4). The highest ascorbic acid levels were found in $0.5 \% \mathrm{WP}$ treated samples. Zhang, Zhaoxin, Zhifang, and Xiang (2005) found that samples where PPO had been inhibited had higher ascorbic acid concentration probably due to the retardation of tissue metabolism. However, our data do not agree with this observation. PPO activity and ascorbic acid levels were lower in samples treated with 3\% WP than in samples treated with $1.5 \%$ and $0.5 \%$ (Table 4 ). These results reflect a negative effect of increasing WP concentration on the ascorbic acid levels.

Table 4

Ascorbic acid levels (mg/g of sample) in fresh-cut lettuce and carrots packaged at 4 -C and sanitized with chlorine (120 ppm) and whey permeate (WP) at $0.5 \%$, $1.5 \%$ and $3 \%$, over 10 storage days

\begin{tabular}{|c|c|c|c|c|c|c|}
\hline \multirow[t]{3}{*}{ Vegetable } & \multirow[t]{3}{*}{ Treatment } & \multirow{3}{*}{$\begin{array}{l}\text { Differences between } \\
\text { treatments ( } p \text { value) }\end{array}$} & \multicolumn{4}{|c|}{ Ascorbic acid (mg gÀ 1 of sample) } \\
\hline & & & \multicolumn{4}{|l|}{ Storage (days) } \\
\hline & & & 1 & 3 & 7 & 10 \\
\hline \multirow[t]{5}{*}{ Lettuce } & $0.5 \% \mathrm{WP}$ & $\mathrm{C}$ & $0.070 \mathrm{~T} 0.07^{\mathrm{c}}$ & $0.061 \mathrm{~T} 0.06 \mathrm{~b}^{\mathrm{c}}$ & $0.057{\mathrm{~T} 0.05^{\mathrm{b}}}^{\mathrm{b}}$ & 0.053 T $0.05 \mathrm{~b}$ \\
\hline & $1.5 \% \mathrm{Wp}$ & $\mathrm{B}$ & 0.066 T $0.06 c$ & $0.050 \mathrm{~T} 0.05 \mathrm{~b}$ & 0.050 T $0.05 \mathrm{~b}$ & 0.050 T $0.05 \mathrm{~b}$ \\
\hline & $3 \% \mathrm{WP}$ & $\mathrm{A}$ & $0.062 \mathrm{~T} 0.06 \mathrm{bc}$ & $0.053 \mathrm{~T} 0.05 \mathrm{~b}$ & $0.041 \mathrm{~T} 0.04 \mathrm{a}$ & 0.037 T 0.03a \\
\hline & Chlorine & $\mathrm{B}$ & 0.060 T $0.06 \mathrm{~b}_{\mathrm{c}}$ & $0.053 \mathrm{~T} 0.05 \mathrm{~b}$ & 0.042 T $0.05 a$ & $0.044 \mathrm{~T} 0.05 \mathrm{ab}$ \\
\hline & $0.5 \% \mathrm{WP}$ & NS & $0.056 \mathrm{~T} 0.01 \mathrm{~b}$ & $0.050 \mathrm{~T} 0.01 \mathrm{ab}$ & 0.046 T $0.01 \mathrm{ab}$ & $0.051 \mathrm{~T} 0.01_{\mathrm{ab}}$ \\
\hline \multirow[t]{3}{*}{ Carrot } & $1.5 \% \mathrm{WP}$ & & $0.056 \mathrm{~T} 0.01 \mathrm{~b}$ & $0.052 \mathrm{~T} 0.01 \mathrm{ab}$ & 0.046 T $0.01 \mathrm{ab}$ & $0.051 \mathrm{~T} 0.01_{\mathrm{ab}}$ \\
\hline & $3 \% \mathrm{WP}$ & & $0.060 \mathrm{~T} 0.01 \mathrm{~b}$ & 0.050 T $0.01 \mathrm{ab}$ & 0.050 T $0.01 \mathrm{ab}$ & 0.045 T $0.01 \mathrm{a}$ \\
\hline & Chlorine & & $0.058 \mathrm{~T} 0.01 \mathrm{~b}$ & 0.050 T $0.01 \mathrm{ab}$ & $0.056 \mathrm{~T} 0.01 \mathrm{~b}$ & 0.050 T $0.01 \mathrm{ab}$ \\
\hline
\end{tabular}

*Values designated by the same letter are not significantly different $(p<0.05)$. Lower case letters are used for comparisons during storage. 
Ascorbic acid in sliced carrots significantly $(p<0.05)$ decreased with all the treatments during storage (Table 4). Lower values were found in samples treated with $0.5 \%$ and $1.5 \%$ WP; however the differences were not significant $(\mathrm{p}<0.05)$.

Total carotenoids in sliced carrots (Fig. 4) showed a significant $(p<0.05)$ decrease during storage. Samples treated with chlorine and 3\% WP had significantly $(p<0.05)$ lower carotenoid concentration than samples treated with $0.5 \%$ and $1.5 \%$ WP. This carotenoid reduction may be due to the high acidification caused by high concentrations of WP and the bleaching effect of chlorine. Although a gradual decrease during storage was found for all the treatments, samples treated with lower WP concentrations had higher values at the end of storage. In general, better nutritional parameters were maintained in samples treated with low WP concentrations $(0.5 \%$ and $1.5 \%$ ) than with the $3 \% \mathrm{WP}$ and chlorine.

\section{Conclusion}

Whey permeate showed good antimicrobial activity when used as a wash treatment for sliced carrots and fresh-cut lettuce. The concentration of WP was an important factor in the control of microbial growth. The antimicrobial effect might be due to the low $\mathrm{pH}$ and lactic acid content of WP. Another explanation of the antimicrobial phenomenon might be associated with the presence of thermo-resistant bacteriocins in the WP and other small bio-active peptides. However, this explanation is conjectural since no analysis for the presence of these peptides was carried out in this study.

Quality parameters in fresh-cut lettuce did not show differences between WP concentration and this was corroborated by the sensory panel data. Higher concentrations of WP gave a higher inhibition of browning-related enzymes. This indicates that perhaps 3\% WP wash treatment allows a longer storage of fresh-cut lettuce. In sliced carrots 3\% WP is more than sufficient for maintaining quality parameters. However, 3\% WP washing is needed for optimal antimicrobial load. Perhaps, an intermediate concentration might prove optimal for both effects. In general ascorbic acid and carotenoids are maintained better for lower WP concentrations than 3\% WP; differences between 3\% WP and chlorine were not found.

These results suggest 3\% WP is a promising formula for decontamination of fresh-cut vegetables although further investigations are needed in order to optimise this treatment in terms of shelf life, nutritional value, safety and quality.

\section{References}

Adams, J. B. (1991). Enzyme inactivation during heat processing of foodstuffs. International Journal of Food Science \& Technology, 26, 1 - 20.

Allende, A., Aguayo, E., \& Artes, F. (2004). Microbial and sensory quality' of commercial fresh processed red lettuce throughout the production chain and shelf life. International Journal of Food Microbiology, 91(2), $109-117$.

AOAC. (1995). Official methods of analysis (16th edR). Washington DC' Association of Official Analytical Chemists.

Beuchat, L. R. (1992). Surface disinfection of raw produce. Dairy, Food and Environmental Sanitation, 12, 6 - 9 .

Bogaert, J. C. (1997). Production and novel applications of natural L(+) lactic acid: Food pharmaceutics and biodegradable polymers. Cerevis, 22, $46-50$.

Bolin, H. R., \& Huxoll, C. C. (1991). Effect of preparation procedures and storage parameters on quality retention of salad-cut lettuce. Journal of Food Science, $56,416-418$.

Brecht, J. K. (1995). Physiology of lightly processed fruits and vegetables. Horticultural Science, 301, 8- 22.

Cherry, J. P. (1999). Improving the safety of fresh produce with antimicrobials. Food Technology, 53, $54-59$

Clare, D. A., \& Swaisgood, H. E. (2000). Bioactive milk peptides (6). Journal of Dairy Science, 83, $1187-1195$

Debevere, J. (1996). Criteria en praktische methoden voor de bepaling van de houdbaarheidsdatum in de etikettering. In G. Temmerman, C. Cremer, M. Thyssen, \& J. Debevere (Eds.), Voedingsmiddelen en recht 2. Etiketterin, houdbaarheid en bewaring (pp. 37 - 64). Brugge' Uitgeverij Die Keure.

Delaquis, P. J., Stewart, S., Toivonen, P. M. A., \& Moyls, A. L. (1999). Effect of warm, chlorinated water on the microbial flora of shredded iceberg lettuce. Food Research International, 32, 7 - 14

Dychdala, G. R. (1991). Chlorine and chlorine compounds. In S. S. Block (Ed.), Disinfection, sterilization, and preservation (4th edR). Philadelphia, PA' Lea and Febiger.

Fonseca, S. C., Oliveira, F. A. R., Brecht, J. K., \& Chau, K. V. (1999). Development of perforation-mediated modified atmosphere packaging for fresh-cut vegetables. In F. A. R. Oliveira, \& J. C. Oliveira (Eds.), Processing foods (pp. $389-404)$. New York' CRC Press.

Galeazzi, M. A. M., Sgarbieri, V. C., \& Constantinides, S. M. (1981). Isolation, purification and physicochemical characterization of poliphenolxidases (PPO) from dwarf variety of banana (Musa cavendishii, L). Journal of Food Science, 46, $150-155$

Graham, N. J. D. (1997). The role of ozone and potassium permanganate in drinking water treatment. 3rd international workshop on drinking water quality management and treatment technology, 5-6 March. Taipei, Taiwan (R.O.C.).

Gross, J. (1991). Carotenoids. Pigments in vegetables: Chlorophyllase and carotenoids (pp. 124 - 128). New York' Van Nostrand Reinhold.

Ihl, M., Aravena, L., Sheuermann, E., Uquiche, E., \& Bifani, V. (2003). Effect of immersion solutions on shelf life of minimally processed lettuce. Lebensmittel-Wissenschaft und-Technologie, 36, 591 - 599.

Kaneko, K., Hayashidani, H., Takahashi, K., Shiraki, Y., Limawongpranee, S. \& Ogawa, M. (1999). Bacterial contamination in the environment of food factories processing ready-to-eat fresh vegetables. Journal of Food Protection, 62, $800-804$.

Kays, S. J. (1991). Postharvest physiological of perishable plant products. New York' Van Nostrand Reinhold.

Kitts, D. D. (1993). Bioactive substances in food identification and potential uses. Canadian Journal of Physiology and Pharmacology, 72, 423 - 434

Loaiza-Velarde, J. G., Tomas-Barberan, F. A., \& Salveit, M. E. (1997). Effect of intensity and duration of heat shock treatment on wound-induced phenolic metabolism in Iceberg lettuce. Journal of the American Society of Horticultural Science, 122, 873 - 877 .

Martin-Diana, A. B., Rico, D., Barry-Ryan, C., Frias, J. M., Mulcahy, J., \& Henehan, G. T. M. (2005a). Comparison of calcium lactate with chlorine as a washing treatment for minimally processed lettuce and carrots: quality and nutraceutical markers. Journal of the Science of Food and Agriculture, $51,391-394$

\section{Acknowledgements}

The authors would like to acknowledge the financial support of the Technological Sector Research (2002 -2006), Dr. Coen for advice on microbiology and Michelle Bermingham for the assistance help in microbiology analysis. Thanks to Glanbia (Ltd Ingredients, Ireland) for the supply of whey permeate. 
Martin-Diana, A. B., Rico, D., Barry-Ryan, C., Frias, J. M., Mulcahy, J., \& Henehan, G. T. M. (2005b). Effect of calcium lactate concentration and temperature washing treatments on quality retention of salad-cut Iceberg lettuce. International Food Research, 38, 729 - 740.

Nykanen, A., Lapvetelainen, A., Hietnen, R. M., \& Kallio, H. (1998). The“ effect of lactic acid, nisin whey permeate sodium chloride and related combinations on aerobic plate count and the sensory characteristics of rainbow trout. Lebensmittel-Wissenschaft und-Technologie, 31, 286 - 290.

Ohlsson, T. (1994). Minimal processing-preservation methods of the futureAn overview. Trends in Food Science and Technology, 5, 341-344.

Page, T., Harris, R. H., \& Epstein, S. S. (1976). Drinking water and cancer mortality in Louisiana. Science, 1993, $55-57$.

Palleroni, N. J. (1984). Pseudomonadaceae. In B. Tansill, C. L. Brown, \& C. S. Nolley (Eds.), Bergey's manual of systematic microbiology (pp. 141 - 219). Basel' Williams and Wilkins.

Ponce, A. G., Roura, S. I., Del Valle, C. E., \& Fritz, R. (2002). Characterization of native microbial population of Swiss Chaed (Beta vulgaris, type cicla). Lebensmittel-Wissenschaft und-Technologie, 37, 199- 204.

Singh, N., Singh, R. K., Bhunia, A. K., \& Stroshine, R. L. (2002). Efficacy of chlorine dioxide, ozone, and thyme essential oil or a sequential washing in killing Escherichia coli 0157: h7 on lettuce and baby carrots. LebensmittelWissenschaft und-Technologie, 35, 720 - 729.

Surjadinata, B. B., \& Cisneros-Zevallos, L. (2003). Modeling wounding induced respiration of fresh-cut carrots (Daucus carots L.). Journal of Food Science, 68, $2735-2740$

Tan, B. K., \& Harris, N. D. (1995). Maillard products inhibit apple polyphenoxidase. Food Chemistry, 53, 267 - 273.

Tyagi, R. D., \& Kluepfel, D. (1998). Bioconversion of cheese whey to organics acids. In A. M. Martin (Ed.), Bioconversion of waste materials to industrial products. Glasgow' Blackie Academic.

Watada, A. E. (1997). Quality maintenance of fresh-cut fruits and vegetables. Food Biotechnology, 6(4), $224-233$.

Watada, A. E., \& Qui, L. (1999). Quality of fresh-cut produce. Postharvest Biology and Technology, 15, $201-205$.

Wei, C. I., Huang, T. S., Kim, J. M., Lin, W. F., Tamplin, M. L., \& Bartz, J. A. (1999). Growth and survival of Salmonella montevideo on tomatoes and disinfection with chlorinated water. Journal of Food Protection, 58, $829-836$.

Zhang, L., Zhaoxin, L., Zhifang, Y., \& Xiang, G. (2005). Preservation of freshcut celery by treatment of ozonated water. Food Control, 16, 279 - 283. 